\title{
Anticonvulsant Effect of Antiaris toxicaria (Pers.) Lesch. (Moraceae) Aqueous Extract in Rodents
}

\author{
Priscilla Kolibea Mante, ${ }^{1}$ Donatus Wewura Adongo, ${ }^{1}$ Eric Woode, ${ }^{1}$ \\ Kennedy Kwami Edem Kukuia, ${ }^{2}$ and Elvis Ofori Ameyaw ${ }^{3}$ \\ ${ }^{1}$ Department of Pharmacology, Faculty of Pharmacy and Pharmaceutical Sciences, \\ Kwame Nkrumah University of Science and Technology, Kumasi, Ghana \\ ${ }^{2}$ Department of Pharmacology, University of Ghana Medical School, University of Ghana, Accra, Ghana \\ ${ }^{3}$ Department of Biomedical and Forensic Sciences, School of Biological Science, University of Cape Coast, Cape Coast, Ghana
}

Correspondence should be addressed to Eric Woode; ewoode.pharm@knust.edu.gh

Received 3 June 2013; Accepted 13 August 2013

Academic Editors: C.-G. Jang, A. Pittaluga, and B.-N. Wu

Copyright (C) 2013 Priscilla Kolibea Mante et al. This is an open access article distributed under the Creative Commons Attribution License, which permits unrestricted use, distribution, and reproduction in any medium, provided the original work is properly cited.

\begin{abstract}
Antiaris toxicaria (Moraceae) was evaluated for anticonvulsant activity in rodents. Animal models used include maximal electroshock test (MEST); pentylenetetrazole-induced (PTZ) convulsions; picrotoxin-induced (PCT) convulsions; strychnine(STR-) and 4-aminopyridine-induced convulsions. Increase in latency to seizures as well as reduction in duration and frequency of seizures indicated anticonvulsant activity. The extract was more effective in all models used except the maximal electroshock test and strychnine-induced convulsions. Antiaris toxicaria aqueous extract $\left(200,400\right.$, and $\left.800 \mathrm{mg} \mathrm{kg}^{-1}\right)$ significantly $(P<0.05-0.01)$ shortened the duration of convulsions in PTZ- and PCT-induced seizures. Delay in the onset of convulsions in the two tests was significant $(P<0.001)$. Reduction in the frequency of seizures was also significant $(P<0.05-0.001)$ in both tests. Antiaris further delayed the onset of seizures in 4 -aminopyridine model while producing $75 \%$ protection against death in mice. Diazepam $\left(0.1,0.3\right.$, and $\left.1 \mathrm{mg} \mathrm{kg}^{-1}\right)$, carbamazepine $\left(3,10\right.$, and $\left.30 \mathrm{mg} \mathrm{kg}^{-1}\right)$, and sodium valproate $\left(100-400 \mathrm{mg} \mathrm{kg}^{-1}\right)$ were used as reference anticonvulsant drugs for various models. Flumazenil blocked the effect of the extract in the PTZ test significantly suggesting that Antiaris toxicaria may be acting by enhancing the effects of the GABAergic system. Antiaris toxicaria aqueous extract therefore possesses anticonvulsant activity.
\end{abstract}

\section{Introduction}

The plant Antiaris toxicaria (family Moraceae) is an indigenous plant common in Ghanaian forests. It is known locally as "foto" or "kyenkyen" in Akan and the bark cloth tree in English [1]. Despite considerable advancements in the treatment of neurological disorders, epilepsy remains a significant therapeutic challenge [2]. Currently available antiepileptic drugs (AEDs) have debilitating adverse effects on cognition and behaviour [3]. These adverse effects are commonly and consistently observed with barbiturates, benzodiazepines, and topiramate $[4,5]$. This problem is further compounded by polypharmacy which characterizes treatment of epilepsy. These problems are known to prevail more in developing countries due to lack of facilities for proper diagnosis and treatment along with monitoring of AED serum levels [6, 7].

Natural products and plants already used in traditional medicine can be a good place to start in the search for safer and more effective options. Numerous plants used for the treatment of epilepsy traditionally have been shown to be potent in models of epilepsy and several such plants remain to be scientifically validated [8]. Leonotis leonurus, Delphinium denudatum, Mimosa pudica, and Synedrella nodiflora are but a few examples [8-10]. Preliminary screening of the aqueous extract of Antiaris toxicaria revealed significant anticonvulsant effect in pentylenetetrazole-induced seizure test [11]. Hence, this study seeks to further explore the extract's potential as an anticonvulsant. 


\section{Materials and Methods}

2.1. Plant Material. Stem bark of Antiaris toxicaria was harvested from the KNUST campus, Kumasi, and authenticated at the Pharmacognosy Department of the Faculty of Pharmacy, KNUST, Kumasi, Ghana. A voucher specimen (KNUST/HM1/011/S007) was retained in the herbarium.

\subsection{Preparation of Antiaris toxicaria Aqueous Extract. Dried} stem bark was milled into powder using a commercial grinder. The coarse powder (431 g) was extracted by cold maceration with distilled water as solvent at room temperature for five days. Filtrate was oven-dried to obtain a yield of $23.40 \%$ w/w of Antiaris toxicaria aqueous extract (AAE).

2.3. Animals. Male ICR mice and Sprague-Dawley rats weighing between 20 and $25 \mathrm{~g}$ and 120 and $145 \mathrm{~g}$, respectively, were obtained from Noguchi Memorial Institute for Medical Research, Accra, Ghana, and kept in the departmental animal house. Animals were maintained under laboratory conditions of temperature, humidity, and light, housed in stainless steel cages $\left(34 \times 47 \times 18 \mathrm{~cm}^{3}\right)$, and allowed access to water and food ad libitum. The animals were assigned to treatment groups of eight to ten animals randomly. All animals were handled in accordance to the Guide for the Care and Use of Laboratory Animals [12] and experiments were approved by the Faculty Ethics Committee.

2.4. Drugs and Chemicals. Diazepam (DZP), pentylenetetrazole (PTZ), picrotoxin (PCT), 4-aminopyridine (4-AP), and strychnine (STR) were purchased from Sigma-Aldrich Inc., St. Louis, MO, USA. Flumazenil was obtained from APP Pharmaceuticals, LLC, Schaumburg, IL, USA.

2.5. Pentylenetetrazole-Induced Seizures. The method as described by Vellucci and Webster, 1984, and Moezi et al., 2011, [13, 14] was used. The plant extract was administered at doses of 200, 400, and $800 \mathrm{mg} \mathrm{kg}^{-1}$ body weight orally. Intraperitoneal (i.p) injection of diazepam (0.1, 0.3, and $1 \mathrm{mg} \mathrm{kg}^{-1}$ ) was used as reference anticonvulsant drug. Animals were pretreated with the plant extract thirty minutes and diazepam fifteen minutes before administration of pentylenetetrazole (PTZ) $85 \mathrm{mg} \mathrm{kg}^{-1}$ subcutaneously. Control animals were pretreated with distilled water $\left(10 \mathrm{~mL} \mathrm{~kg}^{-1}\right.$, p.o.). The onset of, total duration as well as frequency of clonic seizures were measured within a thirty minute period.

2.6. Picrotoxin-Induced Seizures. Animals received AAE at doses of 200, 400, and $800 \mathrm{mg} \mathrm{kg}^{-1}$ (p.o.) body weight. Picrotoxin (PCT) was injected intraperitoneally at a dose of $3 \mathrm{mg} \mathrm{kg}^{-1}$ fifteen minutes after pretreatment with diazepam and thirty minutes after AAE. Diazepam (0.1, 0.3, and $1 \mathrm{mg} \mathrm{kg}^{-1}$ ) served as positive control. Control animals received distilled water $\left(10 \mathrm{~mL} \mathrm{~kg}^{-1}\right.$, p.o. $)$. Anticonvulsant activity was scored similarly to that stated in the PTZ test $[13,15]$.
2.7. Maximal Electroshock Test (MEST). Tonic convulsions of hind limb extremities of mice were induced using electrical current $(50 \mathrm{~mA}, 60 \mathrm{~Hz}$, and 0.2 seconds) via ear clip electrodes. Control group animals received distilled water orally $\left(10 \mathrm{~mL} \mathrm{~kg}^{-1}\right.$, p.o.). Carbamazepine at doses of 3,10 , and $30 \mathrm{mg} \mathrm{kg}^{-1}$ orally served as reference anticonvulsant. AAE was tested at doses of 200, 400, and $800 \mathrm{mg} \mathrm{kg}^{-1}$ orally. Convulsions were induced thirty minutes after pretreatment. Latency to and total duration of hind limb tonic extension were recorded [16].

2.8. Strychnine-Induced Convulsions. This test was carried out as described by Bogdanov et al. in 1997 [17]. AAE was administered orally at doses of 200, 400, and $800 \mathrm{mg} \mathrm{kg}^{-1}$ body weight. Strychnine was injected subcutaneously at a dose of $2 \mathrm{mg} \mathrm{kg}^{-1}$ thirty minutes after AAE administration. Standard anticonvulsant employed was diazepam (0.1, 0.3 , and $1 \mathrm{mg} \mathrm{kg}^{-1}$, i.p). Animals were observed via video recording. The onset of, decrease in the total duration plus frequency of tonic convulsions were taken as indication of anticonvulsant activity.

2.9. 4-Aminopyridine-Induced Convulsions. Animals received AAE orally at doses of 200,400 , and $800 \mathrm{mg} \mathrm{kg}^{-1}$ body weight. 4-Aminopyridine was dissolved in normal saline and injected subcutaneously at a dose of $10 \mathrm{mg} \mathrm{kg}^{-1}$ body weight thirty minutes after drug treatments. Control animals were pretreated with normal saline $\left(10 \mathrm{~mL} \mathrm{~kg}^{-1}\right)$ and sodium valproate at 100,200 , and $400 \mathrm{mg} \mathrm{kg}^{-1}$ served as positive control. Hind limb tonic extensions and decrease in the total duration of convulsions were recorded. Method as described by Morales-Villagrán and Tapia, 1996, [18] was used with slight modifications.

2.10. Effect of $A A E$ on $G A B A_{A}$. In order to investigate the mechanism of action of AAE as an anticonvulsant, mice were treated with flumazenil, a benzodiazepine antagonist ( $1 \mathrm{mg} \mathrm{kg}^{-1}$, i.p) fifteen minutes before the administration of AAE (400 mg kg-1, p.o.). Thirty (30) minutes later, convulsions were induced with pentylenetetrazole at $85 \mathrm{mg} \mathrm{kg}^{-1}$, intraperitoneally. Other groups of animals received AAE or flumazenil or diazepam $\left(0.3 \mathrm{mg} \mathrm{kg}^{-1}\right.$, i.p $)$ only. Animals were observed for thirty minutes after treatment via video recording for latency and duration of convulsions.

2.11. Data Analysis. Analysis of variance (ANOVA) followed by Newman-Keuls' post hoc test was used to determine significant differences between means. Two-way ANOVA followed by Bonferroni test was used in the flumazenil experiment. In the 4-aminopyridine seizure test, the KaplanMeier method was used in estimating survival relative to time and survival differences were analyzed with the log-rank test. Statistical analyses were carried out with Graph Pad Prism Version 5.0 (GraphPad Software, San Diego, CA, USA) and SigmaPlot Version 11.0 (Systat Software, Inc., Chicago, USA). 


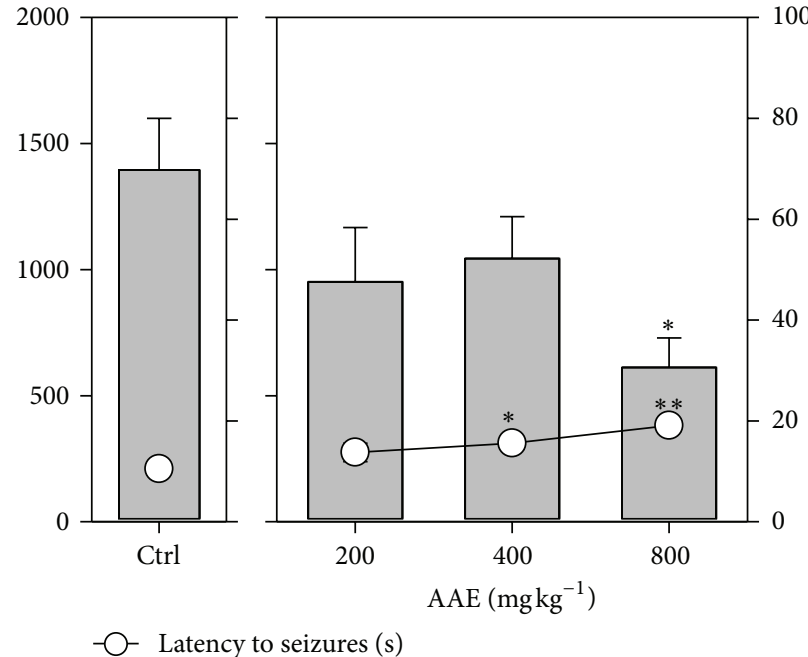

(a)

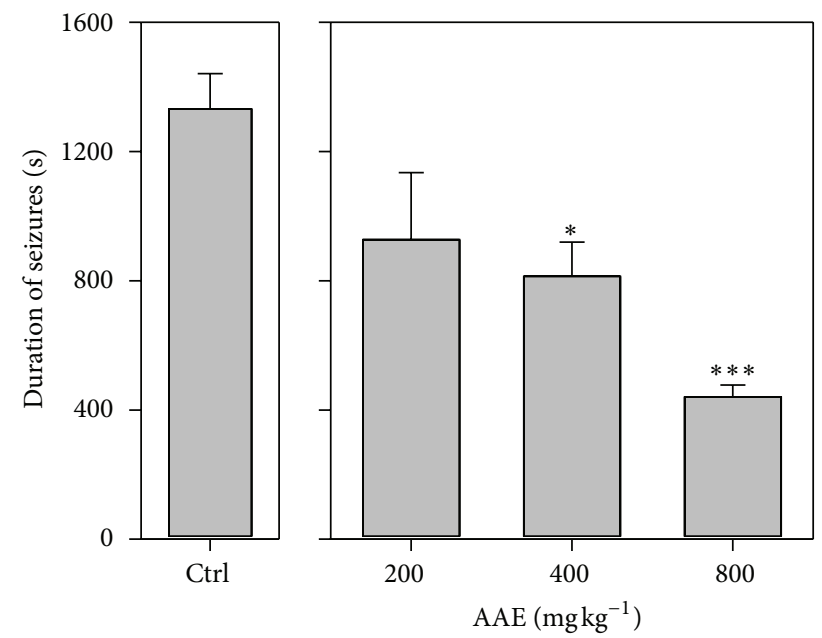

(c)

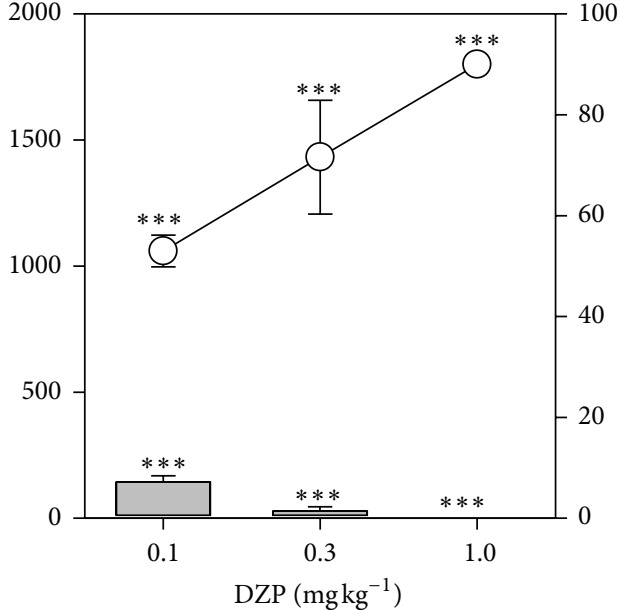

$\square$ Frequency of seizures

(b)

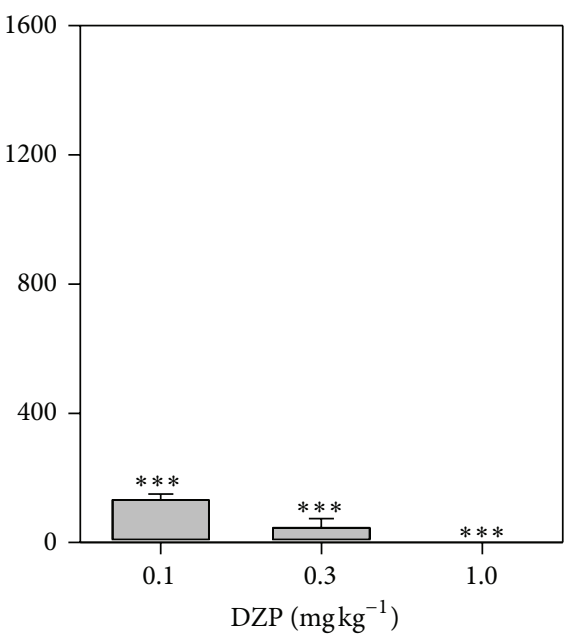

(d)

Figure 1: Effects of $\operatorname{AAE}\left(200,400\right.$, and $800 \mathrm{mg} \mathrm{kg}^{-1}$, p.o. $)$ and diazepam $\left(0.1,0.3\right.$, and $1.0 \mathrm{mg} \mathrm{kg}^{-1}$, i.p. $)$ on the latency and frequency of seizures $((\mathrm{a})$ and $(\mathrm{b}))$ and duration of convulsions ((c) and (d)) in PTZ-induced seizures. Data are presented as mean \pm S.E.M. $(n=8)$. ${ }^{*} P<0.05$, ${ }^{* *} P<0.01$, and ${ }^{* * *} P<0.001$ (one-way analysis of variance followed by Newman-Keuls' post hoc test).

Values were presented as mean \pm S.E.M., and $P<0.05$ was considered significant.

\section{Results}

3.1. Effects in Pentylenetetrazole-Induced Seizures. Pentylenetetrazole $\left(85 \mathrm{mg} \mathrm{kg}^{-1}\right.$, s.c.) produced myoclonic jerks in all mice pretreated with the distilled water. AAE (200$\left.800 \mathrm{mg} \mathrm{kg}^{-1}\right)$ produced a significant $\left(P=0.0021 ; F_{3,16}=\right.$ 7.671; Figure 1(a)) dose-dependent increase in time taken to the onset of clonic seizures. In the extract-treated animals, frequency of seizures was also decreased nondosedependently, and only the $800 \mathrm{mg} \mathrm{kg}^{-1}$ dose was significant $\left(P=0.0511 ; F_{3,16}=3.213\right.$; Figure 1(a) $)$. AAE produced significant $\left(P=0.0018 ; F_{3,16}=8.005\right.$; Figure $\left.1(\mathrm{c})\right)$ dosedependent decrease in the total duration of convulsions in all animals pretreated with the various doses of the extract. The reference anticonvulsant diazepam $\left(0.1-1.0 \mathrm{mg} \mathrm{kg}^{-1}\right.$, i.p) also profoundly delayed the onset of myoclonic jerks, decreased frequency of jerks and significantly $\left(P<0.0001 ; F_{3,16}=\right.$ 125.8; Figures 1(b) and 1(d)) antagonized PTZ-induced seizures.

3.2. Effects in Picrotoxin-Induced Seizures. Picrotoxin $\left(3 \mathrm{mg} \mathrm{kg}^{-1}\right.$, i.p) produced clonic seizures in all mice pretreated with the distilled water. AAE $\left(200-800 \mathrm{mg} \mathrm{kg}^{-1}\right)$ produced a dose-dependent increase in latency to seizures which was significant $\left(P=0.0009 ; F_{3,16}=9.108\right.$; Figure 2(a)) at all doses. The frequency of seizures was also significantly $\left(P=0.0081 ; F_{3,16}=5.591\right.$; Figure $\left.2(\mathrm{a})\right)$ decreased dose-dependently. AAE produced significant $\left(P=0.0002 ; F_{3,16}=12.53\right.$; Figure 2(c) $)$ dose-dependent decrease in the total duration of seizures in all animals. The reference anticonvulsant diazepam $\left(0.1-1.0 \mathrm{mg} \mathrm{kg}^{-1}\right.$, i.p. $)$ also 


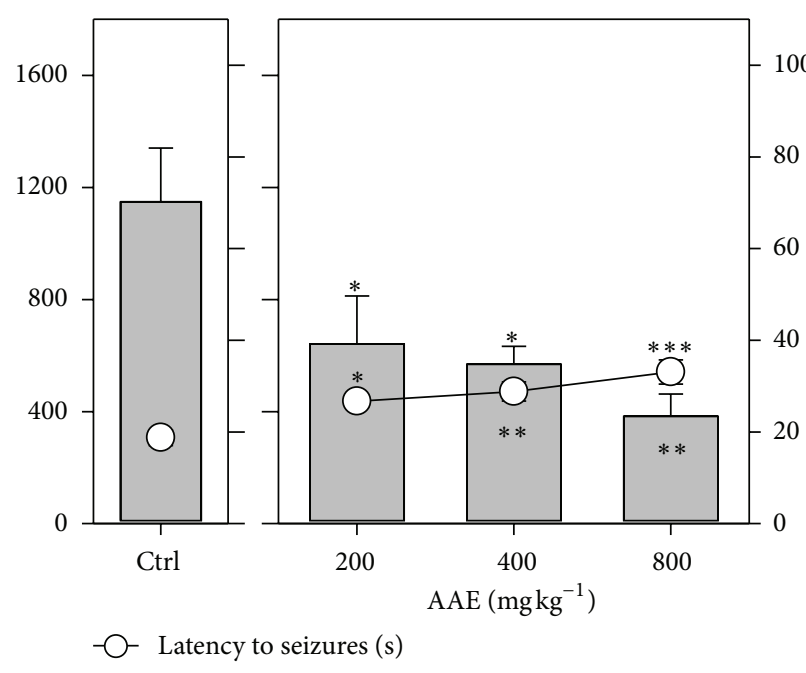

(a)

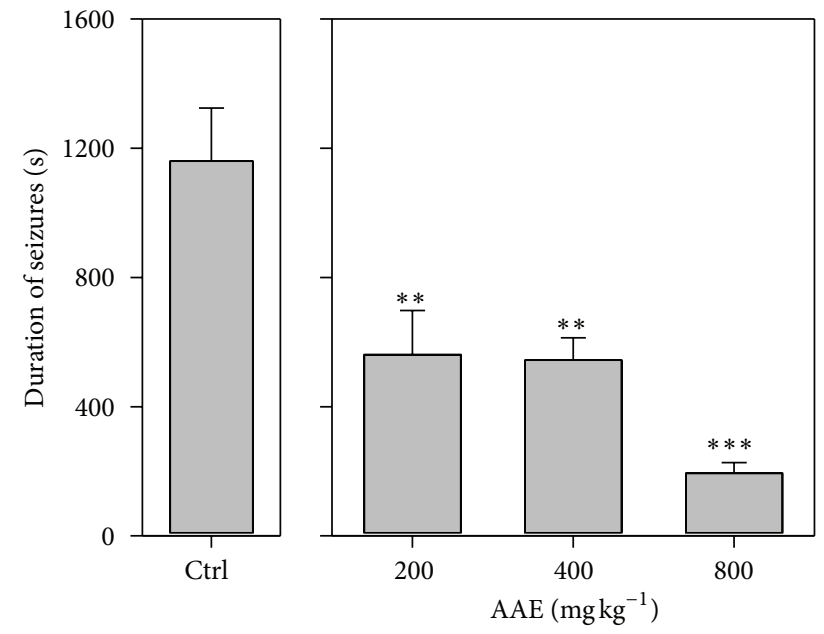

(c)

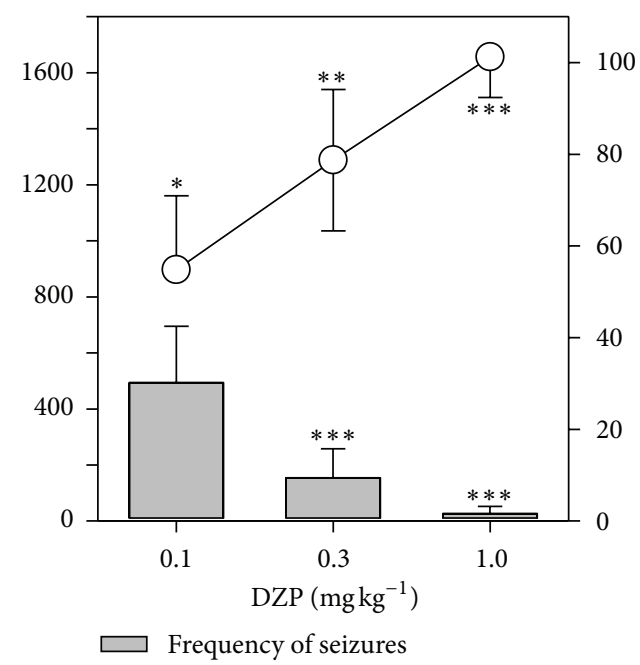

(b)

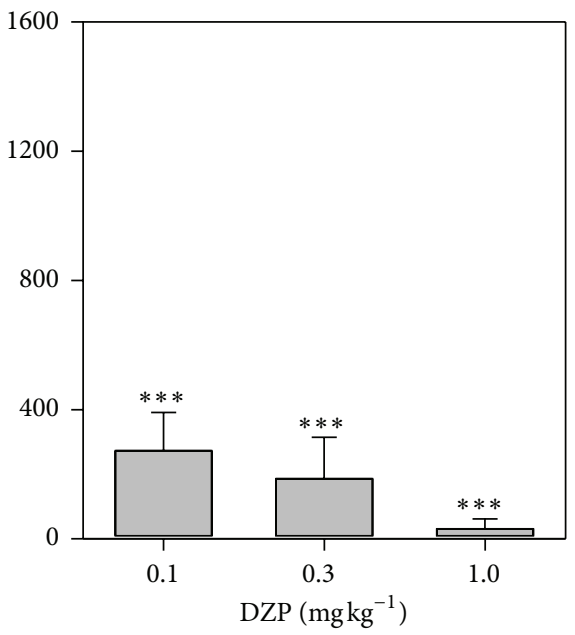

(d)

FIGURE 2: Effects of $\operatorname{AAE}\left(200,400\right.$, and $800 \mathrm{mg} \mathrm{kg}^{-1}$, p.o. $)$ and diazepam $\left(0.1,0.3\right.$, and $1 \mathrm{mg} \mathrm{kg}^{-1}$, i.p.) on the latency and frequency of seizures $((\mathrm{a})$ and $(\mathrm{b}))$ and duration of convulsions ((c) and (d)) in picrotoxin-induced seizures. Data are presented as mean \pm S.E.M. $(n=8)$. ${ }^{*} P<$ $0.05,{ }^{* *} P<0.01$, and ${ }^{* * *} P<0.001$ compared to vehicle-treated group (one-way analysis of variance followed by Newman-Keuls' post hoc test).

profoundly delayed the onset of myoclonic jerks, decreased frequency of jerks and significantly antagonised $(P<0.0001$; $F_{3,16}=17.72$; Figures 2(b) and 2(d)) PCT-induced seizures.

3.3. Effects in Maximal Electroshock Test. Electroshock produced hind limb tonic extensions (HLEs) in all mice. The extract did not affect the latency to onset of hind limb tonic extensions and duration of convulsions significantly (Figure 3). The reference anticonvulsant carbamazepine (3, 10 , and $30 \mathrm{mg} \mathrm{kg}^{-1}$, p.o.), however, delayed the onset of HLEs significantly $\left(P=0.0054 ; F_{3,16}=6.193\right.$; Figure 3$)$ and decreased the total duration of electroshock-induced convulsions.

3.4. Effect in Strychnine-Induced Convulsions. Strychnine produced hind limb tonic extensions (HLEs) in all mice. AAE did not affect the latency to onset of hind limb tonic extensions and duration of convulsions significantly (Figure 4). The reference anticonvulsant diazepam $\left(1 \mathrm{mg} \mathrm{kg}^{-1}\right.$, i.p), on the other hand, delayed the latency to convulsions significantly $\left(P<0.0001 ; F_{4,20}=36.60\right.$; Figure 4$)$. The duration of convulsions was also significantly $\left(P<0.0001 ; F_{4,20}=14.31\right.$; Figure 4) decreased.

3.5. Effects in 4-Aminopyridine-Induced Convulsions. 4-Aminopyridine $\left(10 \mathrm{mg} \mathrm{kg}^{-1}\right.$, i.p.) produced hind limb tonic extensions in all animals. The extract produced a significant $(P<$ $0.0001 ; F_{3,28}=22.02$; Figure 5(a)) increase in time taken to the onset of convulsions. Sodium valproate (100$\left.400 \mathrm{mg} \mathrm{kg}^{-1}\right)$ also significantly $\left(P<0.0001 ; F_{3,28}=17.61\right.$; Figure 5(b)) delayed the onset of convulsions. The extract significantly $\left(P=0.0004, \chi^{2}(\mathrm{df}=3)=18.11\right.$; Figure $\left.6(\mathrm{a})\right)$ 


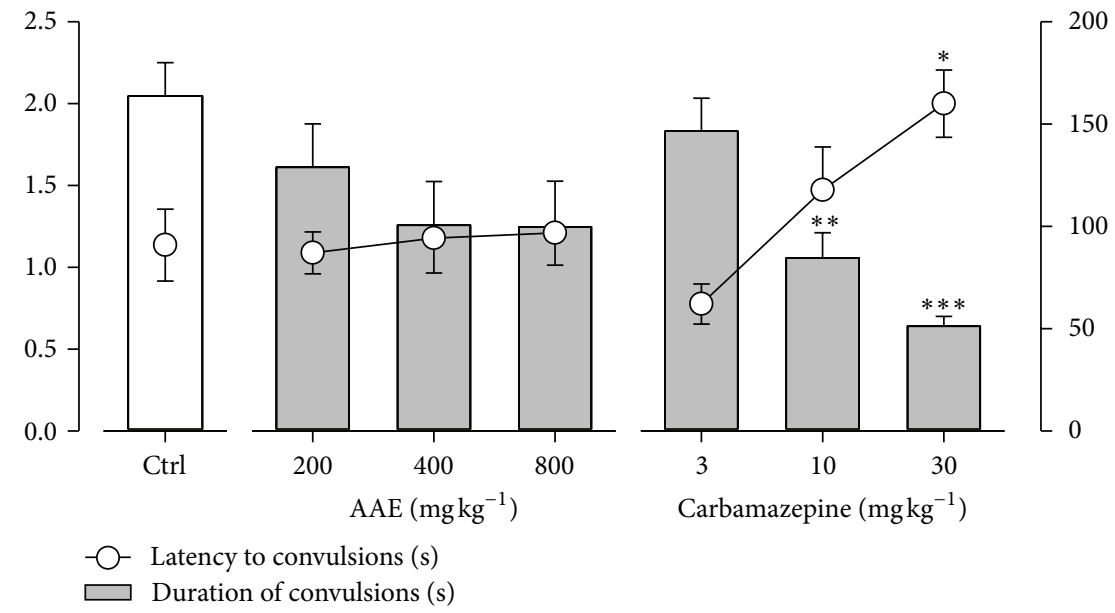

Figure 3: Effects of $\operatorname{AAE}\left(200,400\right.$, and $800 \mathrm{mg} \mathrm{kg}^{-1}$, p.o. $)$ and carbamazepine $\left(3,10\right.$ and $30 \mathrm{mg} \mathrm{kg}^{-1}$, p.o. $)$ on the latency to and duration of convulsions in the MEST. Each point and column represents mean \pm S.E.M. $(n=8)$. ${ }^{*} P<0.05,{ }^{* *} P<0.01{ }^{* * *} P<0.001$ compared to vehicle-treated group (one-way analysis of variance followed by Newman-Keuls' post hoc test).
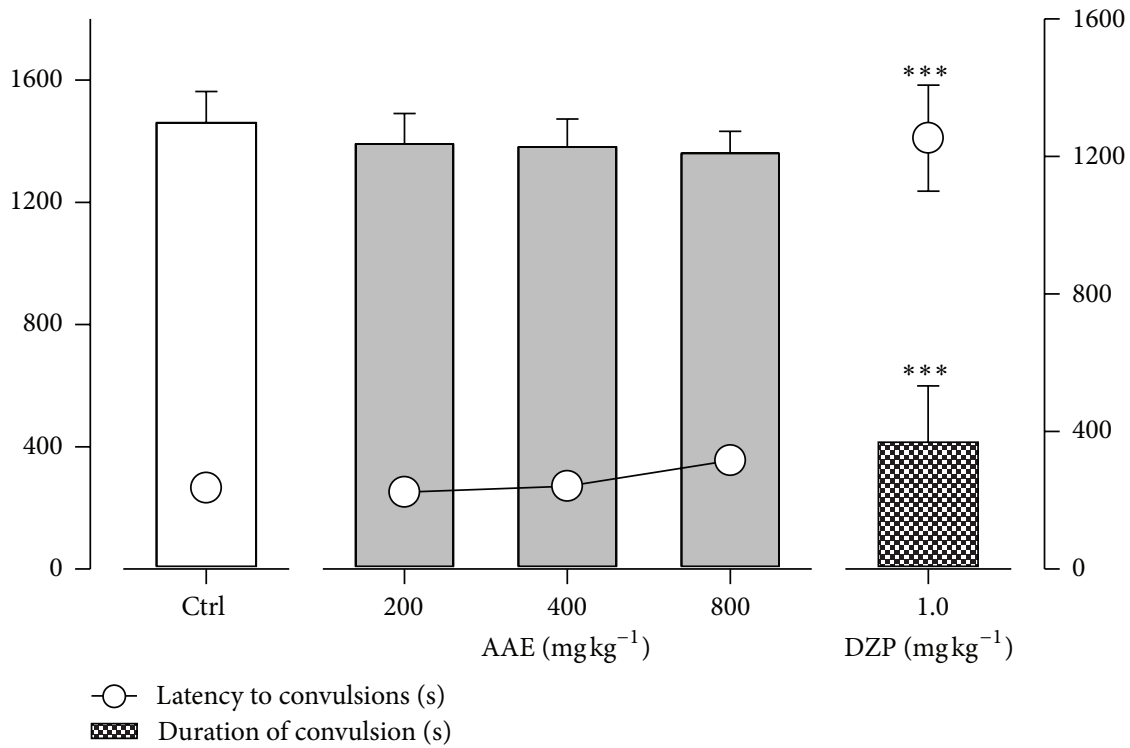

res. Duration of convulsion (s)

Figure 4: Effects of $\operatorname{AAE}\left(200,400\right.$, and $800 \mathrm{mg} \mathrm{kg}^{-1}$, p.o. $)$ and diazepam $\left(1 \mathrm{mg} \mathrm{kg}^{-1}\right.$, i.p.) on the latency to and duration of convulsions in strychnine-induced seizures. Data are presented as mean \pm S.E.M. $(n=10) .{ }^{* * *} P<0.001$ compared to vehicle-treated group (one-way analysis of variance followed by Newman-Keuls' post hoc test).

improved survival of the animals after induction of convulsions. The test for trend presented significant $(P<$ $\left.0.0001, \chi^{2}(\mathrm{df}=1)=15.79\right)$ effect of the treatment groups on median survival indicating a linear trend. Sodium valproate also produced similar effects on survival $(P<$ 0.0001, $\chi^{2}(\mathrm{df}=3)=21.23$; Figure 6(b)) and linear trends $\left(P<0.0001, \chi^{2}(\mathrm{df}=1)=19.17\right)$. Survival curves show a decrease in probability of survival with time. However, probability of survival increased with increasing dose.

3.6. Effects of Flumazenil. Flumazenil significantly $(P=$ $0.0009 ; F_{1,8}=26.09$; Figure $7(\mathrm{c})$ ) reversed the reduction in duration of seizures produced by the extract. A significant reversal $\left(P=0.0003 ; F_{1,8}=37.51\right.$; Figure $\left.7(\mathrm{a})\right)$ was also obtained for the latency to seizures. The frequency of seizures as compared to the control showed no significant effect. Effects of diazepam were significantly $(P<0.0001$; Figures 7(a), 7(b), and 7(c)) reversed by flumazenil.

\section{Discussion}

The outcome of this study provides evidence that the aqueous extract of the stem bark of Antiaris toxicaria possesses anticonvulsant activity. The ability of AAE to delay the onset of convulsions and/or shorten the duration of convulsions was considered an indication of anticonvulsant activity. Judging from the data obtained, the plant extract exhibited 


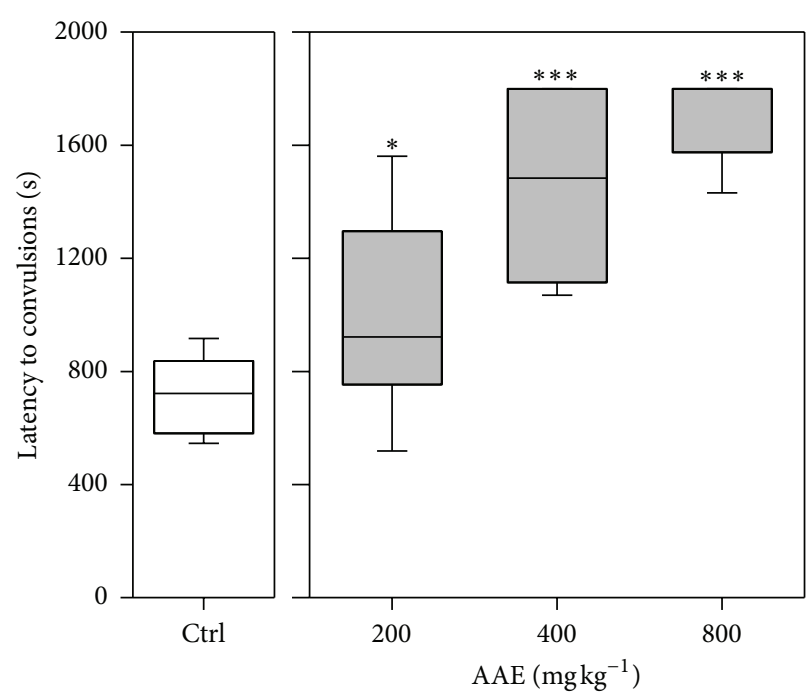

(a)

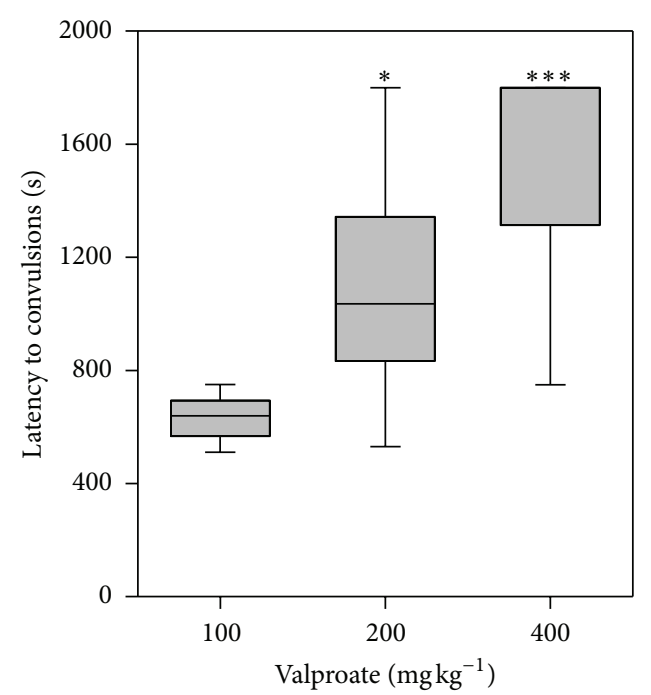

(b)

Figure 5: Effects of AAE $\left(200,400\right.$, and $800 \mathrm{mg} \mathrm{kg}^{-1}$, p.o. $)$ and sodium valproate $\left(100,200\right.$, and $400 \mathrm{mg} \mathrm{kg}^{-1}$, p.o. $)$ on the latency to convulsions in 4-aminopyridine-induced seizure test. Data are presented as group mean \pm S.E.M. $(n=8)$. The lower and upper margins of the boxes represent the 25th and 75th percentiles, with the extended arms representing the 10th and 90th percentiles, respectively. The median is shown as a horizontal line within the box. ${ }^{*} P<0.05,{ }^{* * *} P<0.001$ compared to vehicle-treated group (one-way analysis of variance followed by Newman-Keuls post hoc test).

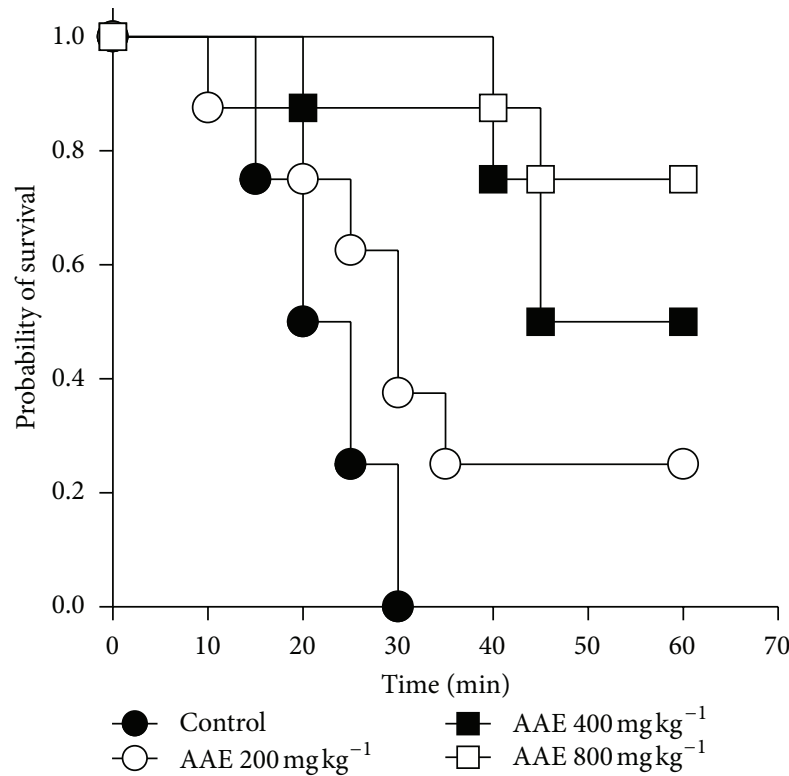

(a)

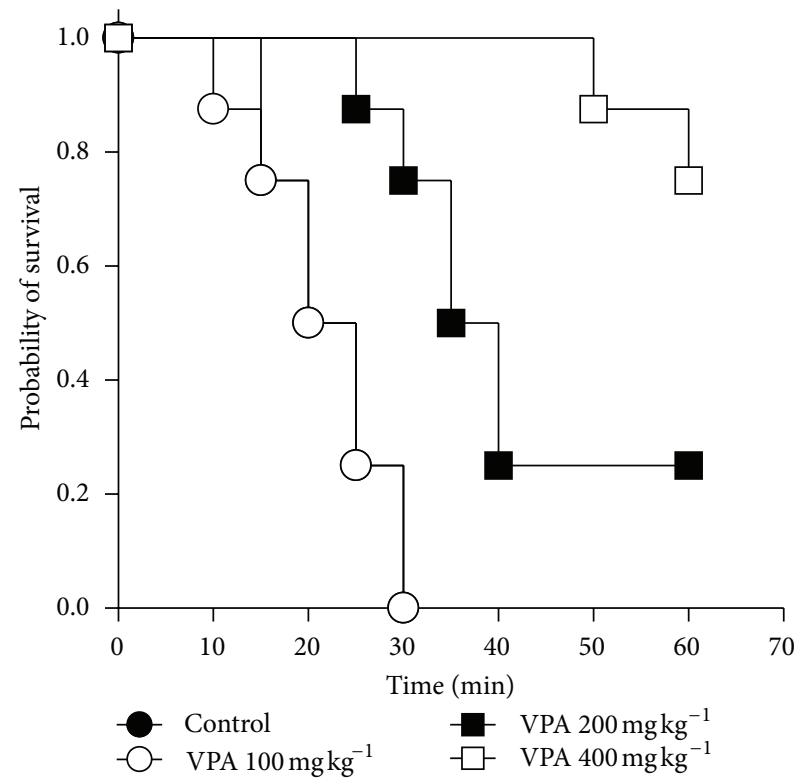

(b)

FIGURE 6: Kaplan-Meier estimates of overall survival of animals treated with (a) AAE (200, 400, and $800 \mathrm{mg} \mathrm{kg}^{-1}$ ) and (b) sodium valproate $\left(100,200\right.$, and $\left.400 \mathrm{mg} \mathrm{kg}^{-1}\right)$ in the 4-aminopyridine seizure test over one-hour observation period $(n=8)$.

anticonvulsant activity in the PTZ test just like diazepam which can be due to action on GABA system [19-21]. The exact mechanism by which PTZ produces seizures is not well understood. It, however, has been shown to be due to inhibition and/or attenuation of GABAergic neurotransmission $[22,23]$. It is therefore likely that AAE produces its anticonvulsant effect directly or indirectly by enhancing GABAergic neurotransmission in the brain. The PTZ test models human generalized and absence seizures [24, 25]. Hence, the extract may be effective in managing such conditions.

Picrotoxin is a $\mathrm{GABA}_{\mathrm{A}}$-receptor antagonist $[26,27]$. GABAergic ionotropic receptors can mediate both pre- and post-synaptic inhibition. Pre-synaptic inhibition mediated by GABA often leads to inhibition of neurotransmitter 


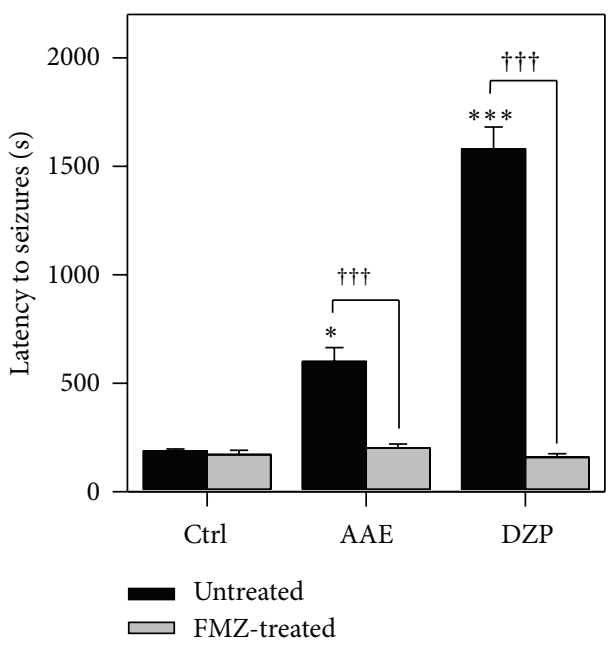

(a)

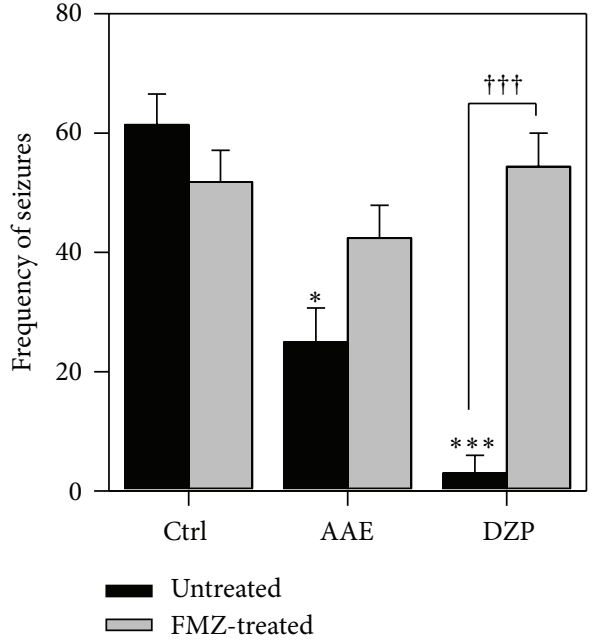

(b)

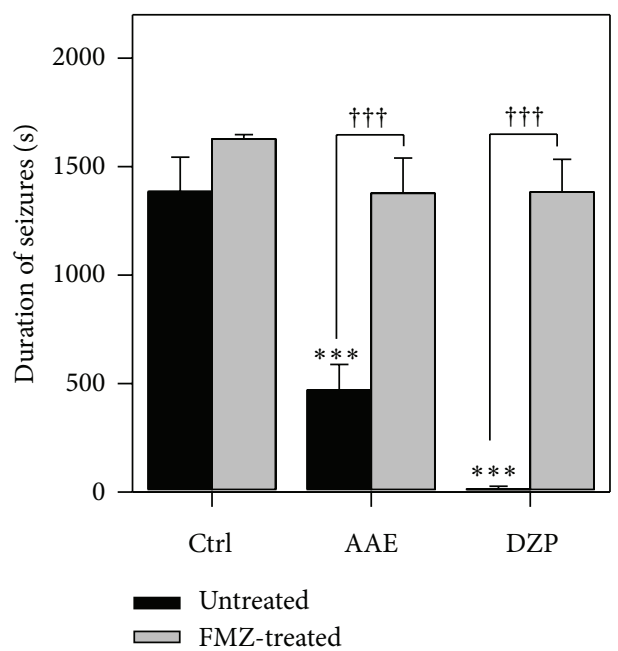

(c)

Figure 7: Effect of flumazenil on the latency (a), frequency (b), and duration of seizures (c) of AAE (400 mg kg-1, p.o.) and diazepam $\left(0.3 \mathrm{mg} \mathrm{kg}^{-1}\right.$, i.p.) (c) in PTZ-induced seizures. Data are presented as mean \pm S.E.M. $(n=8) .{ }^{*} P<0.05$, ${ }^{* *} P<0.01$, and ${ }^{* * *} P<0.001$ compared to vehicle-treated group (one-way analysis of variance followed by Newman-Keuls' post hoc Test). ${ }^{\dagger \dagger \dagger} P<0.001$ (two-way ANOVA followed by Bonferroni posttest).

release from the excitatory arm [28]. PCT-induced seizures which are due to the decreased $\mathrm{GABA}_{\mathrm{A}}$-receptor-mediated inhibition in turn promote the excitatory arm of the CNS mainly mediated by glutamate $[20,22]$. The extract being effective in the PCT-induced seizure test points to a more specific action on GABA-mediated neurotransmission. This has been further confirmed by the use of flumazenil to reverse the anticonvulsant properties of AAE in the PTZ-induced seizure model. Flumazenil is a benzodiazepine antagonist at the $\mathrm{GABA}_{\mathrm{A}}$ receptor possessing the ability to reverse anticonvulsant effects and the accompanying alterations in extracellular glutamate concentration [29]. The specificity of flumazenil to this receptor has been proven as several authors have demonstrated that the antagonist has no effect on diazepam's action on voltage-dependent $\mathrm{Na}^{+}$channels [29-31].
4-Aminopyridine is a potassium ion channel antagonist. AAE significantly and dose-dependently increased the latency to convulsions induced with 4-aminopyridine. This may be due to activation of potassium channels or conductance. GABAergic receptor activation can result in enhancement of potassium conductance. AAE may therefore be acting either directly or indirectly to enhance potassium ion conductance. Retigabine is currently the only approved drug for the treatment of epilepsy which functions through activation of potassium currents [32-34] and has promise in the treatment of pharmacoresistant epilepsy. It is also known that 4-aminopyridine stimulates the release of neurotransmitters, including glutamate, in numerous preparations such as brain slices [35-38] and the neuromuscular junction [39]. Furthermore, it has been recently found by a microdialysis procedure in vivo that glutamate is by far the amino acid 
predominantly released by 4 -aminopyridine in the striatum [18]. Therefore, due to the well-recognized function of excitatory amino acid receptors in convulsive and excitotoxic mechanisms [40], it seems feasible that the excess glutamate released may be involved in the excitatory effects. This indicates that the extract may be acting, in addition to the above, by modulating the release of glutamate. From the pattern of survival curves, it can be inferred that the dose of the extract does affect survival rate offering significant protection against death from 4-aminopyridine-induced convulsions. This was evident from the log-rank analysis which indicated significant differences between survival curves for each dose level. Median survival time ranged from $30 \mathrm{~min}$ and death may be prevented totally at the highest dose of AAE. The exact mechanism by which the extract offers this protection may be linked to its ability to reduce excitotoxic effects mediated by glutamate release. Sodium valproate also increased median survival time and was more effective than the extract.

The extract showed no effect in the MEST at all doses. This indicates that it is not effective in partial and generalized tonic seizures [41] and is unable to prevent seizure spread [8]. It was also ineffective in strychnine-induced convulsions. Strychnine induces convulsions by antagonizing competitively the postsynaptic inhibitory effects of glycine [42]. The fact that AAE produced no protective effects against strychnine-induced convulsions suggests it does not interact with the glycine-mediate inhibitory pathway.

\section{Conclusion}

The results presented here indicate that the aqueous extract of Antiaris toxicaria exhibits anticonvulsant activity, possibly through GABA-mediated inhibition and inhibition of glutamate mediated excitation via activation of potassium ion channels.

\section{Conflict of Interests}

The authors declare that they have no conflict of interests.

\section{References}

[1] R. N. Mshana, Traditional Medicine and Pharmacopoeia, Contribution to the Revision of Ethnobotanical and Floristic Studies in Ghana, Science and Technology Press, CSIR, 2001.

[2] B. A. Chindo, J. A. Anuka, L. McNeil et al., "Anticonvulsant properties of saponins from Ficus platyphylla stem bark," Brain Research Bulletin, vol. 78, no. 6, pp. 276-282, 2009.

[3] J. S. Duncan, "The promise of new antiepileptic drugs," British Journal of Clinical Pharmacology, vol. 53, no. 2, pp. 123-131, 2002.

[4] J. Vermeulen and A. P. Aldenkamp, "Cognitive side-effects of chronic antiepileptic drug treatment: a review of 25 years of research," Epilepsy Research, vol. 22, no. 2, pp. 65-95, 1995.

[5] R. L. Bromley, B. A. Leeman, G. A. Baker, and K. J. Meador, "Cognitive and neurodevelopmental effects of antiepileptic drugs," Epilepsy \& Behavior, vol. 22, no. 1, pp. 9-16, 2011.

[6] M. P. Kvalsund and G. L. Birbeck, "Epilepsy care challenges in developing countries," Current Opinion in Neurology, vol. 25, no. 2, pp. 179-186, 2012.
[7] J. Engel, "Epilepsy global issues for the practicing neurologist,” 2005, http://public.j.eblib.com/EBLPublic/PublicView. do?ptiID=289756.

[8] M. Raza, F. Shaheen, M. I. Choudhary et al., "Anticonvulsant activities of ethanolic extract and aqueous fraction isolated from Delphinium denudatum," Journal of Ethnopharmacology, vol. 78, no. 1, pp. 73-78, 2001.

[9] E. Ngo Bum, D. L. Dawack, M. Schmutz et al., "Anticonvulsant activity of Mimosa pudica decoction," Fitoterapia, vol. 75, no. 3-4, pp. 309-314, 2004.

[10] P. Amoateng, E. Woode, and S. B. Kombian, "Anticonvulsant and related neuropharmacological effects of the whole plant extract of Synedrella nodiflora (L.) Gaertn (Asteraceae)," Journal of Pharmacy and Bioallied Sciences, vol. 4, no. 2, pp. 140-148, 2012.

[11] P. K. Mante, D. W. Adongo, K. K. E. Kukuia, E. O. Ameyaw, and E. Woode, "Neuropharmacological assessment of an aqueous bark extract of Antiaris toxicaria (Pers.) Lesch. (Moraceae) in rodents," American Journal of Pharmacology and Toxicology, vol. 7, no. 4, pp. 123-134, 2012.

[12] NRC, Guide for the Care and Use of Laboratory Animals, The National Academies Press, 1996.

[13] S. V. Vellucci and R. A. Webster, "Antagonism of caffeineinduced seizures in mice by Ro15-1788," European Journal of Pharmacology, vol. 97, no. 3-4, pp. 289-293, 1984.

[14] L. Moezi, H. Shafaroodi, A. Hojati, and A. R. Dehpour, "The interaction of melatonin and agmatine on pentylenetetrazoleinduced seizure threshold in mice," Epilepsy \& Behavior, vol. 22, no. 2, pp. 200-206, 2011.

[15] V. Paul and E. H. Subramanian, "Evidence for an involvement of nitric oxide and gamma aminobutyric acid in the anticonvulsant action of L-arginine on picrotoxin-induced convulsions in rats," Pharmacology Biochemistry and Behavior, vol. 72, no. 3, pp. 515-519, 2002.

[16] W. Loscher, C. P. Fassbender, and B. Nolting, "The role of technical, biological and pharmacological factors in the laboratory evaluation of anticonvulsant drugs. II. Maximal electroshock seizure models," Epilepsy Research, vol. 8, no. 2, pp. 79-94, 1991.

[17] N. N. Bogdanov, I. I. Poletaeva, and N. V. Popova, "Pentylenetetrazol and strychnine convulsions in brain weight selected mice," Seizure, vol. 6, no. 2, pp. 135-138, 1997.

[18] A. Morales-Villagrán and R. Tapia, "Preferential stimulation of glutamate release by 4 -aminopyridine in rat striatum in vivo," Neurochemistry International, vol. 28, no. 1, pp. 35-40, 1996.

[19] B. S. Meldrum, "Epilepsy and $\gamma$ aminobutyric acid mediated inhibition," International Review of Neurobiology, vol. 17, pp. 136, 1975.

[20] K. Gale, "Role of GABA in the genesis of chemoconvulsant seizures," Toxicology Letters, vol. 64-65, pp. 417-428, 1992.

[21] G. De Sarro, G. Ferreri, P. Gareri et al., "Comparative anticonvulsant activity of some 2,3-benzodiazepine derivatives in rodents," Pharmacology Biochemistry and Behavior, vol. 74, no. 3, pp. 595-602, 2003.

[22] K. Gale, "GABA and epilepsy: basic concepts from preclinical research," Epilepsia, vol. 33, supplement 5, pp. S3-S12, 1992.

[23] B. G. Katzung, Basic and Clinical Pharmacology, McGraw-Hill, Boston, Mass, USA, 9th edition, 2004.

[24] W. Loscher and D. Schmidt, "Which animal models should be used in the search for new antiepileptic drugs? A proposal based on experimental and clinical considerations," Epilepsy Research, vol. 2, no. 3, pp. 145-181, 1988. 
[25] N. Upton, "Mechanisms of action of new antiepileptic drugs: rational design and serendipitous findings," Trends in Pharmacological Sciences, vol. 15, no. 12, pp. 456-463, 1994.

[26] M. K. Ticku and R. W. Olsen, " $\gamma$-Aminobutyric acid stimulated chloride permeability in crayfish muscle," Biochimica et Biophysica Acta, vol. 464, no. 3, pp. 519-529, 1977.

[27] R. W. Olsen, “The GABA postsynaptic membrane receptorionophore complex. Site of action of convulsant and anticonvulsant drugs," Molecular and Cellular Biochemistry, vol. 39, pp. 261-279, 1981.

[28] A. B. MacDermott, L. W. Role, and S. A. Siegelbaum, "Presynaptic ionotropic receptors and the control of transmitter release," Annual Review of Neuroscience, vol. 22, pp. 443-485, 1999.

[29] G. M. Khan, I. Smolders, G. Ebinger, and Y. Michotte, "Flumazenil prevents diazepam-elicited anticonvulsant action and concomitant attenuation of glutamate overflow," European Journal of Pharmacology, vol. 407, no. 1-2, pp. 139-144, 2000.

[30] K. H. Backus, P. Pflimlin, and G. Trube, "Action of diazepam on the voltage-dependent $\mathrm{Na}+$ current. Comparison with the effects of phenytoin, carbamazepine, lidocaine and flumazenil," Brain Research, vol. 548, no. 1-2, pp. 41-49, 1991.

[31] Y. Ishizawa, K. Furuya, S. Yamagishi, and S. Dohi, "NonGABAergic effects of midazolam, diazepam and flumazenil on voltage-dependent ion currents in NG108-15 cells," NeuroReport, vol. 8, no. 11, pp. 2635-2638, 1997.

[32] A. Rostock, C. Tober, C. Rundfeldt et al., "D-23129: a new anticonvulsant with a broad spectrum activity in animal models of epileptic seizures," Epilepsy Research, vol. 23, no. 3, pp. 211223, 1996.

[33] C. Rundfeldt, "The new anticonvulsant retigabine (D-23129) acts as an opener of $\mathrm{K}^{+}$channels in neuronal cells," European Journal of Pharmacology, vol. 336, no. 2-3, pp. 243-249, 1997.

[34] B. Hecht, "Retigabine. A novel anticonvulsant drug for the adjunctive treatment of partial seizures," Medizinische Monatsschrift fur Pharmazeuten, vol. 35, no. 5, pp. 166-171, 2012.

[35] P.-S. Hu, C. Benishin, and B. B. Fredholm, "Comparison of the effects of four dendrotoxin peptides, 4-aminopyridine and tetraethylammonium on the electrically evoked $[3 \mathrm{H}]$ noradrenaline release from rat hippocampus," European Journal of Pharmacology, vol. 209, no. 1-2, pp. 87-93, 1991.

[36] P.-S. Hu and B. B. Fredholm, "4-Aminopyridine-induced increase in basal and stimulation-evoked [3H]-NA release in slices from rat hippocampus: $\mathrm{Ca}^{2+}$ sensitivity and presynaptic control," British Journal of Pharmacology, vol. 102, no. 3, pp. 764-768, 1991.

[37] P.-S. Hu, S. Jin, and B. B. Fredholm, "4-Aminopyridine-induced noradrenaline release from the rat hippocampus depends on the activation of glutamate receptors of the non-NMDA type," Acta Physiologica Scandinavica, vol. 143, no. 1, pp. 139-140, 1991.

[38] R. Tapia, L. Medina-Ceja, and F. Peña, "On the relationship between extracellular glutamate, hyperexcitation and neurodegeneration, in vivo," Neurochemistry International, vol. 34, no. 1, pp. 23-31, 1999.

[39] H. Lundh, "Effects of 4-aminopyridine on neuromuscular transmission," Brain Research, vol. 153, no. 2, pp. 307-318, 1978.

[40] B. S. Meldrum, "Excitatory amino acid receptors and disease," Current Opinion in Neurology and Neurosurgery, vol. 5, no. 4, pp. 508-513, 1992.

[41] R. L. Macdonald and M. Kevin Kelly, "Antiepileptic drug mechanisms of action," Epilepsia, vol. 36, supplement 2, pp. S2S12, 1995.
[42] E. D. Bigler, "Comparison of effects of bicuculline, strychnine, and picrotoxin with those of pentylenetetrazol on photically evoked afterdischarges," Epilepsia, vol. 18, no. 4, pp. 465-470, 1977. 

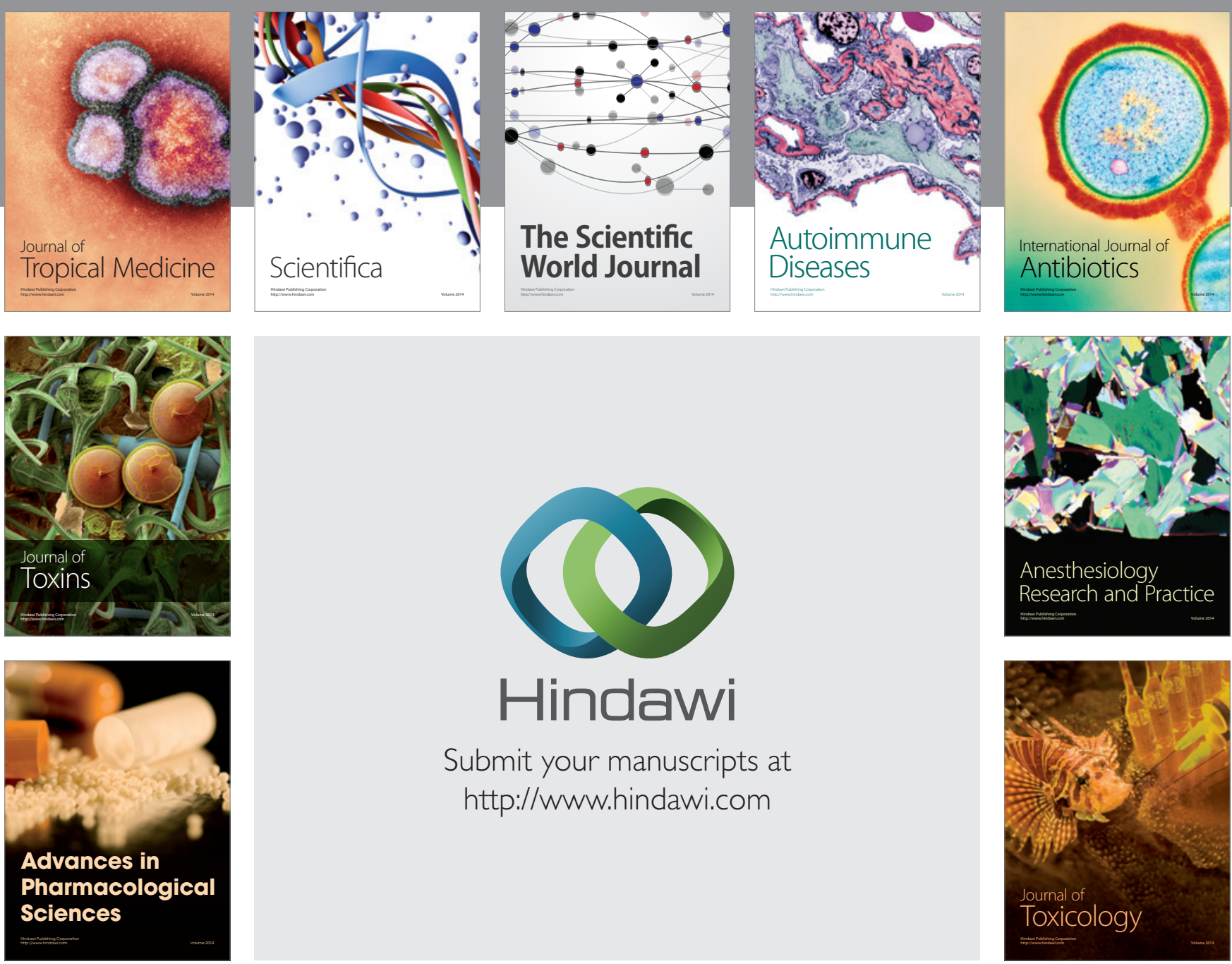

\section{Hindawi}

Submit your manuscripts at

http://www.hindawi.com
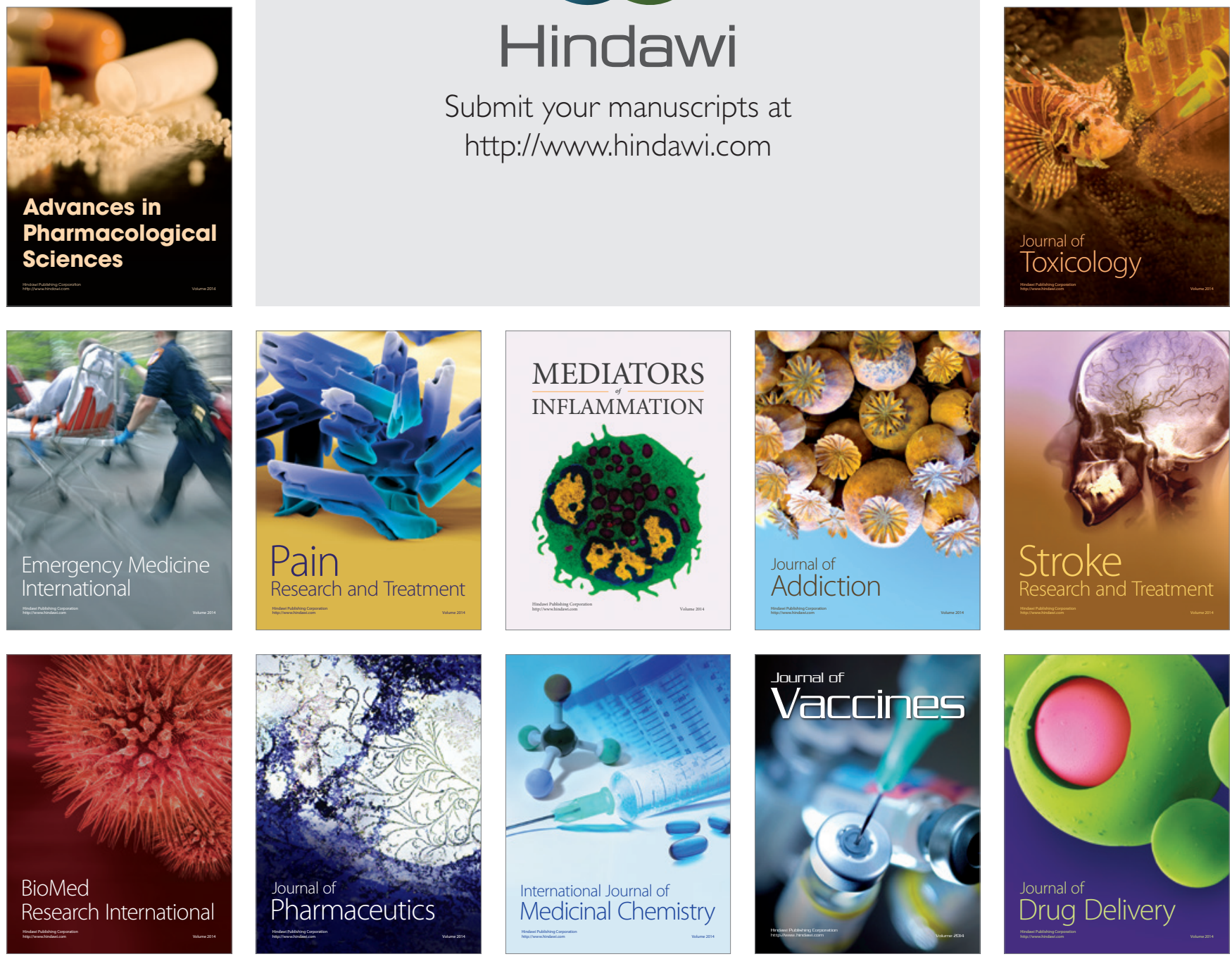